rabbit skeletal myosin II (myosin rod)

I27 has a $\beta$-sandwich structure and unfolds by a three-state mechanism $(\mathrm{N}->\mathrm{I}->\mathrm{U})$. The partial unfolding from the native state $(\mathrm{N}->\mathrm{I})$, in which $\beta$-strand $A$ is peeled off, was unaffected by temperature $\left(2-30{ }^{\circ} \mathrm{C}\right)$. On the contrary, the catastrophic unfolding from the intermediate state $(\mathrm{I}->\mathrm{U})$ was significantly dependent on temperature. The effect of temperature was attributed to the increase of the distance between the intermediate and the transition states in the energy landscape $\left(x_{u}\right)$ at higher temperatures. In addition, the roughness of the energy landscape ( $\varepsilon$ ) was estimated to be $4.3 \mathrm{k}_{\mathrm{B}} \mathrm{T}$, which is similar to that of other proteins.

Myosin-rod consists of two $\alpha$-helical coiled-coils. Upon stretching, the coiled-coil is unravelled by force and shows a plateau in its force-extension curve. The plateau force was seen at around $50 \mathrm{pN}$ and independent of temperature $\left(2-30{ }^{\circ} \mathrm{C}\right)$.

These observations indicate that the effect of temperature on mechanical resistance of the two proteins was distinct from each other, reflecting the difference in the mechanism stabilising their structures. We conclude that loca unfolding reaction of topologically-simple structure is hardly affected by temperature.

\section{P-077 分極可能な力場パラメータに基づくペプチドの自由エネルギーマ} ップ

Free-energy map of a peptide in water calculated with a polarizable force field Tohru Terada (Agricultural Bioinformatics Research Unit, Graduate School of Agricultural and Life Sciences, The University of Tokyo)

Conformational distribution of a peptide in water is quite different from that in vacuo. This difference is caused by the dielectric nature of water: the more polarized structure is the more stable in water. The polarization of the peptide structure occurs at two different levels. At the first level, the peptide is polarized by changing its conformation so that the atoms having positive partial charge gather on one side of the molecule and those having negative partial charges on another side. At the second level, a dipole moment is induced in each atom by the electric field formed by the peptide and the water. Although the latter effect, i.e. the atomic polarizability has been ignored in most of classical simulations, it has been pointed out that taking account of the atomic polarizability is important to accurately describe the interaction between the solute and the water.

To evaluate the effect of the atomic polarizability on the free-energy landscap of a peptide, we performed multicanonical MD simulations on a system composed of an alanine dipeptide and water using polarizable and non-polarizable version of the AMBER force fields. We found that the peptide is more polarized in the simulation with the poralizable force field than in the simulation with the non-polarizable force field. The conformational distributions were slightly different between the two simulations. However, the difference was smaller than that between the simulations conducted with different non-polarizable force fields.

\section{P-078 多孔性シリカゲルを用いたタンパク質折れたたみ反応のスローモ ーション解析}

Slow motion analysis of protein folding reactions within wet porous silica gels Naoya Shibayama (Dept Physiology, Div Biophysics, Jichi Medical University)

Entrapment of proteins in wet, optically transparent, porous silica gel matrices is a promising method to be able to slow down large-scale protein motions while retaining protein integrity and properties in solution. Over the years we have applied this method to study the folding processes of three model proteins, hors cytochrome $c$ (an all $\alpha$-helical protein), bovine $\beta$-lactoglobulin (a predominantly $\beta$-sheet protein which folds through an $\alpha$-helical intermediate) and bovine ubiquitin (an apparent two-state folder), and have compared the results with the corresponding processes occurring in aqueous solution. For all the three proteins studied, the gel entrapment causes a dramatic deceleration of refolding by a facto of $10^{5}-10^{9}$, allowing observation of the entire folding pathways using various spectroscopic techniques. For example, the initial helix formation of these proteins (occurring within milliseconds in solution) can be monitored on a time scale of minutes or hours by far-UV circular dichroism spectroscopy. Moreover, the results on ubiquitin suggest the capability of our approach to stabilize and probe normally unstable high-energy intermediates in apparent two-state folder (the so-called "hidden" intermediates). These results open the way for identifying a sequence of folding events that likely occurs but has been only partly observed in solution experiments.

1P-079 水のエントロピーに注目したタンパク質の熱安定性解析

Analysis on thermal stability of a protein focused on water entropy

Ken-ichi Amano (1), Takashi Yoshidome (1), Yuichi Harano (2), and Masahiro Kinoshita (I). (1: Institute of Advanced Energy, Kyoto University; 2: Global Edge Institute, Tokyo Institute of Technology)

In our view, upon protein folding the restriction of the translational motion of water molecules in the whole system is remarkably reduced, leading to a great gain of the water entropy: Protein folding is driven primarily by this water-entropy effect. On the basis of this view, up to now we have succeeded in discriminating the native fold from a number of misfolded decoys with $100 \%$ accuracy. Pressure and cold denaturations have also been elucidated using a theoretical approach where the water entropy is treated as the key quantity. Here we consider thermal denaturation. We calculate the water-entropy gain upon the transition from a fully extended structure to the native one for many proteins using the angle-dependent integral equation theory combined with the multipolar water model and the morphometric approach. We find that the water-entropy gain divided by the number of residues is a good measure of the protein stability against thermal denaturation. That is, a protein with a larger value of this measure ends to be thermally more stable (i.e., tends to have a higher denaturation temperature)

\section{P-080 好熱性細菌 Thermus thermophilusイソクエン酸脱水素酵素は当該 環境でナノ構造複合体を形成し結晶化する}

Supramolecular complex formation and crystallization of isocitrate dehydrogenase from Thermus thermophilus HB8

Noriyuki Ishii(1), Kazuo Umemura(2) and Kentaro Miyazaki(1,3). (1: Institute for Biological Resources and Functions, National Institute of Advanced Industrial Science and Technolog (AIST); 2: Department of Environmental Energy Engineering, Faculty of Engineering, Musashi Institute of Technology; 3: Department of Medical Genome Sciences, Graduate School of Frontier Sciences, Univ of Tokyo)

Atomic force microscopy (AFM) observation of a crystal surface of the thermostable isocitrate dehydrogenase (ICDH) from a thermophilic eubacterium, Thermus thermophilus HB8, has suggested that the crystal consists of huge homo-complexed ellipsoidal bodies of the protein, with averaged long and short axes' diameters of $18.6 \mathrm{~nm}$ and $10.9 \mathrm{~nm}$ respectively. The thick diamond-shaped crystals with a size about $0.4 \mathrm{~mm}$ in the longest axis have been obtained by the vapor diffusion method from a solution of $100 \mathrm{mM}$ sodium cacodylate, $\mathrm{pH} 6.6$ 8.4 , containing $1.4 \mathrm{M}$ sodium acetate as the precipitate, which diffract X-rays at $3.7 \AA$ resolution. The crystals belong to the monoclinic lattice type with the space group $C 2$ and have cell dimensions of $\mathrm{a}=495.5, \mathrm{~b}=189.2, \mathrm{c}=336.2 \AA$, and $\beta=126.4^{\circ}$, indicating that an asymmetric unit contains more than 33 molecules with a molecular mass of $54.2 \mathrm{kDa}$. The calculation based on the data obtained by X-ray method show good agreement with the AFM observation. The HPLC gel filtration column chromatography of the protein co-exist with its crystals incubated under the critical crystallization condition, and further supporting our assumptions. These results suggest the possibility that the residing T. thermophilus HB8 ICDH molecules are piled one on top another as a preformed supramolecular nano-architecture in the crystal lattice. The system appears suitable for further investigation using a bottom-up approach to the self-associated construction of nano-architectures with proteins.

\section{$1 \mathrm{P}-081$ 基準振動解析における結合モードに基づくタンパク質複合体の動 的構造の分類}

Classification of dynamic structures of protein complexes by the distribution of binding normal modes

Shigeru Endo (1) and Hiroshi Wako (2) (1: Dept Physics, School of Science, Kitasato Univ. 2: School of Social Sciences, Waseda Univ.

In the normal mode analysis of a protein complex the displacement of each atom relative to the center of mass of a molecule in the complex, called internal motion, is obtained by applying an Eckart condition just to the molecule. The external motion is the difference between the normal mode of the whole complex and the internal motion. The translation-rotation vector of the motion of the center of mass of the molecule was calculated from averaging the external motion of all the atoms within the molecule. We defined binding normal modes which had large translation-rotation components in the external motion. In the analyzed dozens kinds of protease-inhibitor complexes, antigen-antibody ones, and other general heterodimers the mode with a significant translational motion existed hardly and the rotational component was localized only to a few modes. It is suggested that the dynamic structure of the complex could be classified from the distribution of binding normal modes. In some examples three rotational vectors perpendicularly intersecting each other were found.

The analyzed results were registered in ProMode (the database of normal mode analyses of proteins; http://promode.socs.waseda.ac.jp). Web pages that display the internal motion, the external motion, and their correlation for each molecule were added to the database server.

\section{P-082 蛋白質タンデムリピートの天然変性構造}

Non-globular of tandem repeats in proteins

Norio Matsushima (1) and Robert H. Kretsinger (2).(1: Div Biophysics, School of Health Sciences, Sapporo Medical Univ; 2: Dept Biology, Univ of Virginia)

Tandem repeats occur in 14 percent of all proteins. The repeat unit length varies considerably from a single amino acid as in polyglutamine to longer than 100 residues as in spectrin. The repeat number is sometimes over 100; for example, in the cytoskeletal protein, titin. Understanding the structures, functions, and evolution of these repeats is a significant goal in both proteomics and genomics. Structures of tandem repeats may be classified into three classes. The first is tandem repeats such as ankyrin, HEAT, leucine rich repeat, and armadillo that form a belical arrangement of repeating structural units (called solenoid structures). The second is tandem repeats such as the zinc-finger (17-31 residues long) and $\mathrm{EF}$ hands ( 29 residues) that assume unique, stable conformations; these repeats do not form a solenoid structure. The third class is tandem repeats that are flexible or disordered in solution under (near) physiological conditions, which we proposed recently (1). In the previous paper we reviewed tandem repeats that are rich in Pro, Gly, Asp, Ser, and/or Thr. Here we review structural studies of other tandem repeats and discuss the structure and function. (1) Matsushima N Yoshida H, Kumaki Y, Kamiya M, Tanaka T, Izumi Y, Kretsinger RH. Flexible Structures and Ligand Interactions of Tandem Repeats Consisting of Proline 